\title{
“EFEKTIVITAS KOMUNIKASI INTERPERSONA ANTARA GURU DAN SISWA \\ DALAM PROSES BELAJAR MENGAJAR DI SMK NEGERI 7 AMBON"
}

\author{
Oleh Marleen Muskita, SP., M.Si
}

\begin{abstract}
Abstrak
Efektivitas komunikasi interpersona antara guru dan siswa dalam proses belajar mengajar di SMK Negeri 7 ambon merupakan penelitian dengan tujuan untuk mengetahui bagaimana efektivitas komunikasi interpersona guru dan siswa dalam proses belajar mengajar di SMK Negeri 7 Ambon. Pendekatan yang digunakan dalam penelitian ini adalah pendekatan kualitatif dengan menggunakan metode penelitian studi kasus. Dari hasil penelitian ini dilihat bahwa siswa kadang tidak mengerti materi yang diberikan oleh guru dan kesulitan dalam membuat tugas karena cara penyampaian materi oleh guru dianggap kurang jelas oleh siswa. Dan kedekatan secara pribadi antara siswa dan guru, sehingga juga mempengaruhi proses belajar mengajar di kelas.
\end{abstract}

Kata Kunci : Efektivitas, Komunikasi Interpersona, Belajar

\section{PENDAHULUAN}

Setiap orang pasti pernah berkomunikasi dengan orang lain baik secara verbal maupun non verbal. Begitu juga di dunia kerja atau organisasi, tidak seseorang yang tidak berkomunikasi dengan yang lainnya. Komunikasi merupakan keharusan bagi manusia dalam rangka membentuk atau melakukan pertukaran informasi. Pertukaran informasi secara pribadi, baik berupa gagasan, ide, atau pendapat diri tujuannya membangun kesamaan pandangan secara pribadi, sebagai pemenuhan kebutuhan membangun kepuasan komunikasi secara tatap muka dan lebih bersifat pribadi antar mereka yang berkomunikasi.

Komunikasi interpersonal (antar pribadi) adalah proses penyampaian panduan pikiran dan perasaan seseorang kepada seorang lainnya agar mengetahui, mengerti, atau melakukan kegiatan tertentu. Menurut Joseph De Vito (1976) dalam sugiyo (2005), "komunikasi antar 
pribadi merupakan pengiriman pesan-pesan dari seseorang dan diterima oleh orang lain, atau juga sekelompok orang dengan efek dan umpan balik yang langsung". Dari inti ungkapan itu, De Vito berpendapat bahwa "Komunikasi antar pribadi sebenarnya merupakan suatu proses sosial" (Liliweri, 2009:12). Pentingnya komunikasi antar pribadi dalam kehidupan manusia tidak dapat dipungkiri, begitu juga dalam lembaga organisasi. Organisasi merupakan suatu wadah sekumpulan orang yang mempunyai kepentingan dan tujuan yang sama, dimana dalam aktifitasnya membutuhkan komunikasi yang baik.

Salah satu organisasi yang dikenal oleh masyarakat luas yaitu sekolah. Sekolah merupakan lembaga yang bertujuan untuk meningkatkan pengetahuan mengenai etika, moral, serta kedisiplinan. Prestasi belajar siswa disekolah merupakan tanda peningkatan pengetahuan dan hal tersebut seharusnya disertai dengan etika dan moral yang baik. Dalam upaya pencapaian tujuan pendidikan disekolah tersebut, maka peranan yang dimiliki oleh guru dalam mendidik siswa sangat penting untuk meningkatkan kualitas siswa baik dalam hal prestasi maupun tingkah laku.

Sekolah memerlukan guru yang memiliki kompetisi mengajar dan mendidik, yang inovatif, yang kreatif, yang cukup waktu untuk menekuni tugas profesionalnya, yang dapat menjaga wibawanya dimata para siswanya. Jadi guru merupakan faktor kunci keberhasilan pelaksanaan pendidikan dan pengajaran, artinya segala kebijakan rencana inovasi gagasan pendidikan yang ditetapkan berasal dari guru.

Efektivitas Komunikasi Antar Pribadi dalam proses belajar mengajar untuk mewujudkan cita-cita pendidikan nasional, yang pada akhirnya mutu pelaksanaan terletak ditangan guru. Adapun dalam belajar mengajar proses penyampaian pesan sumbernya bisa dari murid, guru, dan lain sebagainya. Media pendidikan adalah salurannya, dan penerimanya.

Pelajar atau siswa adalah seseorang yang sedang menginjak usia remaja, yang merupakan masa transisi dari kanak-kanak ke dewasa. Siswa menengah umum ini rata-rata berusia 15 sampai 18 tahun. Pada usia inilah akan timbul berbagai macam gejolak jiwa, keragu-raguan yang dapat menimbulkan kesulitan-kesulitan dalam dirinya. Selain itu juga, penggunaan smartphone dengan berbagai aplikasi dapat mengalihkan perhatian siswa dari proses belajar di rumah maupun di sekolah. Kesulitan-kesulitan yang datang tentu akan menyebabkan rasa ketidakpuasan siswa yang dapat mengganggu konsentrasi belajar. 
Permasalahan ini membuat tugas sebagai pengajar menjadi lebih berat, karena guru harus menghadapi berbagai perbedaan sifat dan sikap secara individual. Dengan komunikasi interpersonal (antar pribadi) secara persuasif dan efektif, apakah komunikasi antara guru kepada siswanya dalam proses belajar mengajar dapat membantu motivasi serta mendorong siswa untuk bergerak kearah yang positif.

\section{TINJAUAN PUSTAKA}

\subsection{Efektivitas}

Efektifitas merupakan wujud dari kemampuan untuk mendayagunakan sesuatu secara tepat sesuai dengan standar yang jelas dan dapat diterima secara universal. Dalam konteks ini efektivitas menunjukkan taraf mencapai tujuannya secara ideal, taraf efektivitasnya dapat dinyatakan dengan ukuran-ukuran yang agak pasti.

Sebagian mengemukakan bahwa efektivitas adalah "pemanfaatan sumber daya, dana, sarana, dan prasarana dalam jumlah tertentu yang secara sadar diterapkan sebelumnya untuk menghasilkan sejumlah barang atau jasa dengan mutu tertentu pada waktunya (Sondang, 2007). Hal ini menunjukkan bahwa efektivitas sebagai suatu kegiatan yang tepat sasaran, berdaya guna dan berhasil guna untuk mencapai tujuan dalam implementasi suatu kegiatan tertentu.

Untuk mengetahui tingkat efektivitas sesuatu kegiatan biasanya dilakukan dengan membandingkan antara prestasi saat ini dengan prestasi yang diperoleh apabila semua sumber daya yang dimilikinya dikelola dengan secara optimal dan objektif.

\subsection{Komunikasi Interpersona}

\subsubsection{Pengertian Komunikasi Interpersona}

Komunikasi interpersona atau komunikasi antar pribadi adalah hubungan antar manusia. (human relation) yang menunjuk kepada interaksi atau seperangkat keterampilan untuk berkomunikasi secara efektif. Baik secara verbal maupun non verbal dengan ciri langsung, kedekatan secara fisik, melibatkan nepercayaan, keterbukaan, keakraban, dan kehangatan dalam dalam kadar tertentu (Mapiare, 2006:179).

Ciri-ciri Komunikasi Antar Pribadi Sugiyo (2005:5) menyebutkan bahwa dalam komunikasi antarpribadi terdapat beberapa ciri utama, antara lain:

a. Keterbukaan, yaitu adanya kesediaan antara dua belah pihak untuk membuka diri dan mereaksi kepada orang lain, merasakan pikiran dan perasaan orang lain.

b. Adanya empati dari komunikator, yaitu suatu penghayatan terhadap perasaan orang lain atau turut merasakan apa yang dirasakan orang lain. 
c. Rasa positif, yaitu kecenderungan bertindak kepada komunikator denagn memberikan penilaian positif terhadap komunikan.

d. Kesamaan, kesamaan menunjukan kesetaraan antara komunikator dan komunikan. Dalam komunikasi antar pribadi, kesetaraan ini merupakan ciri yang penting dalam keberlangsungan dan bahkan keberhasilan komunikasi antarpribadi.

e. Arus pesan yang cenderung dua arah, yaitu adanya hubungan antara komunikator dan komunikan saling member dan menerima informasi.

f. Tatap muka, yaitu suatu komunikasi yang berlangsung secara langsung dan adanya ikatan psikologis serta saling mempengaruhi secara intens.

g. Tingkat umpan balik yang tinggi, adalah bahwa apa yang disampaikan dalam komunikasi sudah sampai kepada penerima, yang ditandai dengan ketergantungan interaktif.

Pendapat lain dari Arni Muhammad (2002:165-168) tujuan komunikasi interpersonal tidak perlu disadari pada saat terjadinya pertemuan dan juga tidak perlu dinyatakan. Tujuan itu boleh disadari dan boleh tidak disadari, boleh disengaja ataupun tidak disengaja. Tujuannya adalah sebagai berikut:

1) Menemukan diri sendiri. Salah satu tujuan komunikasi antar pribadi adalah menemukan personal atau pribadi. Bila kita terlibat dalam pertemuan interpersonal dengan orang lain kita belajar banyak sekali tentang diri kita maupun orang lain. Komunikasi interpersonal memberikan kesempatan kepada kita untuk berbicara tentang apa yang kita sukai atau mengenai diri kita.

2) Menemukan dunia luar. Hanya komunikasi antar pribadi menjadikan kita dapat memahami lebih banyak tentang diri kita dan orang lain yang berkomunikasi dengan kita. Banyak informasi yang kita ketahui datang dari komunikasi interpersonal, meskipun banyak jumlah informasi yang datang kepada kita dari media massa hal itu seringkali didiskusikan dan akhirnya dipelajari atau didalami melalui interaksi interpersonal.

3) Membentuk dan menjaga hubungan penuh arti. Salah satu keinginan orang yang paling besar adalah membentuk dan memelihara hubungan dengan orang lain. Banyak dari waktu yang kita pergunakan untuk komunikasi antar pribadi diabadikan untuk membentuk dan menjaga hubungan sosial dengan orang lain.

4) Berubah sikap dan tingkah laku. Banyak waktu kita pergunakan untuk mengubah sikap dan tingkah laku orang lain dengan komunikasi interpersonal. Kita dapat menginginkan mereka memilih cara tertentu, misalnya mencoba diet yang baru, membeli barang tertentu, menulis membaca buku, memasuki bidang tertentu dan percaya bahwa sesuatu itu benar atau salah. 
5) Untuk bermain dan kesenangan. Bermain mencakup semua aktivitas yang memiliki tujuan utama untuk mendapat kesenangan. Berbicara dengan teman mengenai aktivitas kita pada waktu akhir pekan, berdiskusi mengenai olahraga, menceritakan cerita lucu pada umumnya hal tersebut adalah pembicaraan untuk menghabiskan waktu.

6) Untuk membantu. Ahli-ahli kejiwaan, ahli psikologi klinis dan ahli terapi menggunakan komunikasi interpersonal dalam kegiatan profesional mereka untuk mengarahkan kliennya. Kita semua juga berfungsi membantu orang lain dalam interaksi interpersonal kita seharihari. Kita berkonsultasi dengan seorang teman yang putus cinta, berkonsultasi dengan mahasiswa tentang mata kuliah yang sebaiknya diambil dan sebagainya.

\subsubsection{Komunikasi Interpersona yang Efektif}

Dalam kajian mengenai efektivitas komunikasi interpersonal Devito mengungkapkan bahwa: Efektivitas Komunikasi Interpersonal dimulai dengan lima kualitas umum yang dipertimbangkan yaitu :

1) Keterbukaan atau openess adalah suatu sikap dimana tidak ada perasaan tertekan ketika melakukan kegiatan komunikasi yang ditandai dengan kesediaan untuk jujur dalam menyampaikan apa yang sedanng dirasakan dan sedang dipikirkan.

2) Empati, adalah suatu sikap ikut merasakan apa yang dirasakan oleh lawan bicara, yang ditandai dengan kesediaan mendengarkan dengan sepenuh hati, merespon secara tepat setiap perilaku yang muncul dalam kegiatan komunikasi.

3) Dukungan yaitu suatu sikap memberikan respon balikan terhadap apa yang dikemukakan dalam kegiatan komunikasi, sehingga dalam kegiatan komunikasi terjadi pola dua arah.

4) Rasa positif, adalah suatu perasaaan memandang orang lain dalam kegiatan komunikasi sebagai manusia. Hal ini ditandai dengan sikap Efektivitas Komunikasi Antar Pribadi dalam Mencegah Kenakalan Siswatidak mudah men judge dalam setiap kegiatan interaksi dalam komunikasi.

5) Kesamaan, adalah suatu kondisi dimana dalam kegiatan komunikasi terjadi posisi yang sama antara komunikan dankomunikator, tidak terjadi dominasi antara satu dengan yang lain. hal ini ditandai arus pesan yang dua arah.

\subsubsection{Hambatan dalam Komunikasi Interpersona}

Tiga aspek yang termasuk dalam hambatan komunikasi interpersonal menurut Sunarto (2003:17) yaitu :

a) Hambatan mekanik, yakni hambatan yang timbul akibat adanya gangguan pada saluran komunikasi, seperti terganggunya saluran magnetik radio oleh getaran-getaran sehingga pesan yang disampaikan menjadi kurang jelas. 
b) Hambatan semantik, yang sering terjadi dalam tahap proses komunikasi, karena berkisar pada masalah apa yang dikomunikasikan dan disampaikan pada tahap-tahap komunikasi. Suatu pesan akan berarti lain pada seseorang dalam konteks yang berbeda, hal ini disebabkan adanya gangguan pada komunikator karena salah persepsi.

c) Hambatan manusiawi, segala masalah yang paling semu dalam proses komunikasi adalah masalah yang timbul karena berasal dari dalam diri manusia sendiri. Terjadi karena faktor emosi dan prasangka pribadi, kemampuan atau ketidakmampuan alat panca indera.

\subsection{Sekolah}

Sekolah adalah lembaga yang dirancang untuk pengajaran siswa/murid di bawah pengawasan guru. Sebagian besar Negara memiliki pendidikan formal, yang umumnya wajib. Kata sekolah berasal dari Bahasa Latin: skhole, scola, scolae atau skhola yang memiliki arti: waktu luang atau waktu senggang, dimana ketika itu sekolah adalah kegiatan di waktu luang bagi anak-anak di tengah-tengah kegiatan utama mereka, yaitu bermain dan menghabiskan waktu untuk menikmati masa anak-anak dan remaja. Kegiatan dalam waktu luang itu adalah mempelajari cara berhitung, cara membaca huruf dan mengenal tentang moral (budi pekerti) dan estetika (seni).

Saat ini, kata sekolah berubah arti menjadi: merupakan bangunan atau lembaga untuk belajar dan mengajar serta tempat menerima dan memberi pelajaran. Sekolah dipimpin oleh seorang Kepala Sekolah. Kepala sekolah dibantu oleh wakil kepala sekolah. Jumlah wakil kepala sekolah di setiap sekolah berbeda, tergantung dengan kebutuhannya. Ketersediaan sarana dalam suatu sekolah mempunyai peran penting dalam terlaksananya proses pendidikan (Idi, 2011).

Setiap sekolah memiliki komponen-komponen sarana fisik seperti lahan, bangunan ( kantor, ruang belajar), kurikulum, dan orang-orang (guru, pimpinan, karyawan dan pelajar). Komponen-komponen tersebut menyumbang dengan fungsi dan peranannya untuk keberhasilan lebaga. Guru umumnya merujuk pendidikan professional dengan tugas utamanya mendidik, mengajar, membimbing, mengarahkan, melatih, menilai, dan mengevaluasi peserta didik. Sebagai sebuah system, sekolah mempunyai keterkaitan dengan sistem lain yang jumlahnya tidak sedikit. Sistem luar itu meliputi antara lain orang tua siswa, komuniti sekitar sekolah, dan lain-lain.

\section{METODE PENELITIAN}




\subsection{Jenis Penelitian}

Pendekatan yang digunakan dalam penelitian ini adalah pendekatan kualitatif dengan menggunakan metode penelitian studi kasus. Jenis penelitian studi kasus yakni menyelidiki sistematis atau suatu kejadian atau keadaan yang disebut sebagai kasus untuk memberikan penjelasan yang jujur dan seksama tentang suatu kasus tertentu dengan menggunakan caracara yang sistematis dalam melakukan pengamatan, pengumpulan data, analisis informasi, dan pelaporan hasilnya. Sehingga pembaca dapat memeriksa kebenaran tafsiran penulisannya dengan meninjau sejumlah data obyektif pilihan yang sesuai, yang dijadikan tumpuan untuk membangun studi kasus (Nisbet : 1994).

\subsection{Lokasi Penelitian}

Penelitian ini dilaksanakan di SMK Negeri 7 Ambon yang meliputi siswa kelas XII.

\subsection{Jenis dan Sumber Data}

Jenis dan sumber data terdiri dari data primer dan data sekunder. Dapat dilihat penjelasannya di bawah ini yaitu :

a. Data Primer : data yang dihimpun secara langsung dari sumber berupa tanggapan langsung Informan yang didapat melalui Wawancara dan Observasi. Data primer disebut juga data asli atau data baru. Data ini juga diperoleh langsung dilapangan oleh penulis.

b. Data Sekunder : data pendukung penulis yang didapat dari bacaan-bacaan atau laporan-laporan peneliti terdahulu biasanya berupa arsip kepustakaan. Data sekunder ini disebut juga data tersedia. Data sekunder dalam penelitian ini berupa buku, majalah, internet dan sumber lain yang relevan dengan penelitian ini.

\subsection{Teknik Pengumpulan Data}

Dalam penelitian ini digunakan beberapa teknik pengumpulan data, bertujuan agar data-data yang dikumpulkan relevan dengan permasalahan penelitian. Adapun teknikteknik pengumpulan data dalam penelitian ini adalah Teknik Observasi, Wawancara dan Teknik Dokumentasi.

\section{HASIL PENELITIAN}


Data yang disajikan pada bagian ini berupadata kuesioner siswa dan data hasil wawancara dengan guru. Berdasarkan data yang diperoleh dari kegiatan penelitian yang dilaksanakan maka dapat disajikan sebagai berikut:

\section{1. Proses Belajar Mengajar di Sekolah}

Kuesioner kepada siswa dibuat dalam bentuk pertanyaan. Pertanyaan yang dibuat untuk mengukur seberapa aktif interaksi antara guru dan siswa untuk menciptakan efektivitas komunikasi interpersonal dalam proses belajar mengajar. Selain itu, pertanyaan dibuat untuk mengukur kemampuan siswa dalam memahami materi yang diberikan guru sehingga pada akhirnya dapat membandingkan pernyataan guru dan pernyataan siswa. Dari 20 siswa yang diteliti, ditemukan 4 siswa yang tidak puas dengan interaksi komunikasi interpesona dari guru jurusan Multimedia SMK 7 Ambon.

Berdasarkan data kusioner yang ada, disimpulkan bahwa kedekatan guru di sekolah dengan siswa-siswi cukup dekat. Materi yang diberikan guru menurut sebagian besar siswa dapat dimengerti. Sebagian kecil siswa ada juga yang tidak dimengerti karena cara penyampaian materi oleh guru dianggap kurang dapat dimengerti. Guru juga kadang memberikan kesempatan untuk bertanya kepada siswa dan mendengar keluhan tentang materi yang disampaikan. Siswa selalu saja menemukan kesulitan jika mengerjakan tugas. Dalam penyampaian materi guru menggunakan bahasa yang jelas. Saat menegur murid kadang guru bersikap sopan,kadang juga tidak. Sikap guru juga membuat siwa kadang malas ke sekolah. Guru selalu memposisikan diri sebagai teman. Guru selalu menjelaskan ulang Materi yang kurang dimengerti, selalu saja ada proses belajar mengajar diluar sekolah.

Kedekatan antara guru dan murid sangat berpengaruh terhadap prestasi belajar siswa karena siswa sangat merasakan pentingnya kedekatan tersebut, karena dari hal tersebut siswa bisa mendalami materi / Bertanya kepada guru jika tidak dimengertidan juga guru adalah orang tua sekaligus teman untuk sisa jika mereka ingin menceritakan masalah pribadi mereka dan perlu solusi.

\subsection{Efektivitas Guru dan Siswa}

Wawancara yang dibuat dengan guru untuk mengetahui seberapa efektifnya komunikasi interpesona yang terjadi antara guru dan siswa. Disusun 15 pertanyaan yang berkaitan dengan proses interaksi yang terjadi saat proses belajar mengajar.Dan dapat hasilnya bahwa guru selalu memberikan kesempatan bagi siswa untuk bertanya bila ada 
penjelasan yang kurang dimengerti. Guru telah menganggap siswa-siswanya sebagai teman sehingga interaksi yang terjadi tidak hanya sebatas saat mengajar saja, karena guru juga hadir saat mereka mengalami masalah. Karena masalah yang dialami oleh siswanya dapat mempengaruhi proses belajar mereka disekolah. Selain tu dari hasil wawancara, guru mengatakan bahwa dalam proses belajar mengajar, untuk dapat memotivasi siswanya untuk tetap belajar giat, sering guru memberi apresiasi dalam bentuk sederhana kepada siswanya yang beprestasi seperti mentraktirnya makan. Hal lainnya yang diyakini dapat membangkitkan minat belajar adalah dengan proses belajar diluar ruangan atau praktek. Seperti proses pembuatan film pendek maupun film documenter di beberapa tempat. Namun, memang tidak dapat dipungkiri bahwa masih ada siswa yang faktanya tetap malas. Entah dalam proses pembelajaran di kelas maupun dalam mengerjakan tugas di rumah.

Dari data kuesioner dan hasil wawancara dan data kuesioner dapat dianalisa bahwa upaya yang dilakukan dalam hal berkomunikasi oleh guru untuk meningkatkan minat belajar siswa sudah maksimal. Seperti dengan memposisikan diri sebagai teman sehingga interaksi yang diciptakan lebih akrab dan tidak ada tekanan dalam proses belajar mengajar. Dalam hasil wawancara guru menyatakan bahwa proses komunikasi terjadi diluar lingkup proses belajar mengajar, guru membuka diri untuk siswa dapat bercerita tentang masalah pribadinya. Sebab, masalah pribadi dinilai guru, dapat menghambat siswa-siswinya dalam proses pembelajaran di kelas.

Namun, menurut data kuesioner siswa ditemukan bahwa sebagian kecil siswa tidak merasakan kedekatan secara pribadi terhadap guru, sehingga mempengaruhi proses belajar mengajar di kelas. Hasilnya sebagian kecil siswa kurang memahami materi yang disampaikan. Artinya, komunikasi interpesona yang dilakukan oleh guru belum merata dampaknya terhadap siswa-siswinya.

\section{Kesimpulan Dan saran}

\subsection{Kesimpulan}

1. Siswa kadang tidak mengerti materi yang diberikan oleh guru karena cara penyampaian materi oleh guru dianggap kurang jelas. Siswa selalu saja menemukan kesulitan jika mengerjakan tugas. Dan saat menegur murid kadang guru bersikap tidak sopan atau kasar sehingga dengan sikap guru tersebut juga membuat siwa kadang malas ke sekolah. 
2. Siswa tidak merasakan kedekatan secara pribadi terhadap guru, sehingga mempengaruhi proses belajar mengajar di kelas. Hasilnya sebagian kecil siswa kurang memahami materi yang disampaikan. Artinya, komunikasi interpesona yang dilakukan oleh guru belum merata dampaknya terhadap siswa-siswinya.

\subsection{Saran}

1. Perlu adanya perhatian lebih dari guru dalam proses belajar mengajar serta materi yang diberikan juga harus jelas. Dan juga guru harus melakukan komunikasi interpersona dengan siswa untuk lebih dekat dengan siswa di sekolah.

2. Sekolah harus lebih memperhatikan perkembangan siswa-siswa di sekolah dalam prestasi belajar mereka.

\section{DAFTAR PUSTAKA}

Abdullah Idi, 2011. Sosiologi Pendidikan (Individu, Masyarakat dan pendidikan). Jakarta : PT. Raja Grafindo Persada.

Muhamad Arni. 2002. Komunikasi Organisasi. Jakarta : PT. BumiAksara.

Sugiyo, (2005). Memahami Penelitian Kualitatif. Bandung :Alfabeta.

Sunarto, A.W., (2013). Komunikasi Interpersonal. Yogyakarta : Graha Ilmu. 